\title{
High frequency equipment promotes antibacterial effects dependent on intensity and exposure time
}

This article was published in the following Dove Press journal:

Clinical, Cosmetic and Investigational Dermatology

\author{
Evellyn Claudia Wietzikoski \\ Lovato' \\ Patrícia Amaral Gurgel \\ Velasquez' \\ Cristiana dos Santos \\ Oliveira' \\ Camila Baruffi' \\ Thais Anghinoni' \\ Raquel Costa Machado' \\ Francislaine Aparecida dos \\ Reis Lívero² \\ Samantha Wietzikoski Sato' \\ Lisiane de Almeida Martins' \\ 'Laboratory of Microbiology of \\ Natural Products, Paranaense \\ University, Umuarama, Brazil; \\ ${ }^{2}$ Laboratory of Preclinical Research \\ of Natural Products, Paranaense \\ University, Umuarama, Brazil
}

Correspondence: Evellyn Claudia Wietzikoski Lovato

Laboratory of Microbiology of Natural

Products, Paranaense University, Praça

Mascarenhas de Moraes, 4282, Caixa

Postal 224, CEP 87.502-2I0, Umuarama,

PR, Brazil

Tel +55 44362 I 2849

$\mathrm{Fax}+554436212828$

Email evellyn@prof.unipar.br
Background: The indiscriminate use of antibiotics has caused bacteria to develop mechanisms of resistance to antibacterial agents, limiting treatment options. Therefore, there is a great need for alternative methods to control infections, especially those related to skin. One of the alternative methods is the high frequency equipment (HFE), which is used on skin conditions as an analgesic, an anti-inflammatory, and mainly to accelerate cicatricial processes and have a bactericidal effect through the formation of ozone. This research investigated the antibacterial effect of HFE on standard cultures of bacteria.

Materials and methods: Dilutions $\left(10^{4}\right.$ colony forming unit $\left.\mathrm{mL}^{-1}\right)$ were performed for Enterobacter aerogenes and Staphylococcus aureus with 24-hour growth bacteria. Then, $1 \mu \mathrm{L}$ of each dilution was pipetted into suitable medium and the HFE flashing technique was used at intensities of 6,8 and $10 \mathrm{~mA}$ for 30,60, 90, 120 and 180 seconds. The control group received no treatment. Plates were incubated at $37^{\circ} \mathrm{C}$ for 24 hours and then read.

Results: The spark at intensity of $6 \mathrm{~mA}$ had no bactericidal effect on the E. aerogenes; however, a significant bacterial growth reduction occurred at intensity of $8 \mathrm{~mA}$ after 120 and 180 seconds, and at $10 \mathrm{~mA}$, reduction in bacterial growth could already be verified at 30 seconds and total bacterial growth inhibition occurred in 180 seconds. For $S$. aureus, there was a strong bacterial growth inhibition at all intensities used; however, at $6 \mathrm{~mA}$, absence of bacterium growth after 120 and 180 seconds was observed. By increasing the flashing intensity to 8 and $10 \mathrm{~mA}$, it was observed that the bacterium growth was inhibited after only 30 seconds of irradiation.

Conclusion: The HFE has time-dependent antibacterial effects against $E$. aerogenes and $S$. aureus bacteria that have several resistance mechanisms.

Keywords: bactericidal, bacterial viability, gram negative bacteria, gram positive bacteria, Enterobacter aerogenes, Staphylococcus aureus

\section{Introduction}

Over the last few decades, the development of more efficient drugs against bacterial infections has revolutionized medical treatment, causing a drastic reduction in mortality caused by microbial diseases. On the other hand, the widespread use of antibiotics has lamentably led bacteria to develop defenses against antibacterial agents, resulting in increasing resistance, imposing serious limitations on the options for treating bacterial infections, which is a major threat to public health. ${ }^{1,2}$ In the world scenario of bacterial resistance, bacteria of the genus Enterobacter and Staphylococcus stand out and the antibiotics used to control them are usually not effective, making treatment difficult. ${ }^{3}$

The genus Enterobacter is characterized as facultative anaerobic gram-negative bacilli belonging to family Enterobacteriaceae. Two of its species, Enterobacter 
aerogenes and Enterobacter cloacae are opportunistic bacteria and stand out as pathogens of intensive care unit patients capable of developing resistance mechanisms to $\beta$-lactams. ${ }^{4}$ The greater the expression of the Amp-C gene by Enterobacter, the greater the mechanism of resistance to certain antibiotics such as cephalosporin, and there are reports of carbapenemase-producing strains. ${ }^{5}$

On the other hand, Staphylococcus aureus is a bacterium of the gram-positive cocci group found in the skin and nasal passages of healthy individuals; it is the main etiological agent of skin infections due to its ability to change the integrity of the skin barrier. S. aureus can cause serious infections such as pneumonia, meningitis, endocarditis, septicemia and even systemic infections, which can lead to death. Furthermore, infections caused by this agent present high morbidity and mortality rates in both hospital and home-based cases. ${ }^{3}$ The high ability of this bacterium to acquire resistance to antimicrobials has made it an important etiology of hospital infections, causing it to become a worldwide concern. ${ }^{6,7}$

Since the discovery of treatment-resistant $S$. aureus in the 1950s, several outbreaks of hospital and community infections have been associated with resistant bacteria, viruses and parasites. ${ }^{8}$ In fact, a high prevalence of purulent skin infections caused by $S$. aureus is commonly observed in general practice and in the emergency department. ${ }^{9}$ Furthermore, antimicrobial drug resistance is one of the most important reasons that change the epidemiological behavior of diseases, leading to an increase in prevalence and lethality of several diseases that were previously considered under control. ${ }^{8}$

Due to the great importance of the evolution of microbial resistance and the need for control of hospital and nonhospital infections, it is necessary to develop new bacteriostatic and bactericidal agents that improve the therapy of infected individuals. One of the promising alternatives is the high frequency equipment (HFE). HFE produces alternating currents (high voltage and low intensity), has vacuum or gas glass electrodes that conduct current and ionize air molecules, forming fluorescence. The effect of ozone $\left(\mathrm{O}_{3}\right)$ formed by the current-generated spark when it crosses the electrode and the thermal action of the equipment generated by the electric field formation are responsible for the physiological effects observed. For example, the local peripheral vasodilation that improves blood flow and oxygenation stands out., 3

The equipment is widely used by physiotherapists and aesthetics professionals to treat skin conditions, as an analgesic, anti-inflammatory and mainly to accelerate cicatricial processes. ${ }^{3,10,11}$ In contact with the skin, $\mathrm{O}_{3}$ is converted into molecular oxygen $\left(\mathrm{O}_{2}\right)$ and atomic oxygen $(\mathrm{O})$, which is extremely aggressive due to its oxidative capacity. The effectiveness of $\mathrm{O}_{3}$ action on bacteria is guaranteed because it acts on the bacterial membrane by compromising its enzymatic activity, altering the cell permeability, and causing oxidation of amino acids and nucleic acids, leading to bacterium death. ${ }^{3,10,12}$

In this context, this research investigated the bactericidal action, many times and in many intensities, of HFE in standard $S$. aureus and E. aerogenes strains and determined the sensitivity of this electrotherapeutic resource on these bacteria.

\section{Materials and methods Bacterial culture and count}

For reactivation, E. aerogenes (ATCC ${ }^{\circledR} 13048$ ) and $S$. aureus (ATCC 25923) strains were placed in brain heart infusion agar (BHI) for 24 hours at $37^{\circ} \mathrm{C}$. After clouding the BHI broth for 2-4 hours, ${ }^{13}$ a new peel was performed on Mueller Hinton agar (MHA) for tests with microorganisms. Plates were incubated at $37^{\circ} \mathrm{C}$ for 24 hours. For solid-state tests, after reactivation, bacteria were peeled into their respective culture media and incubated at $37^{\circ} \mathrm{C}$ for 24 hours.

Starting from a culture of 24-hour bacteria growth in appropriate culture medium, a sterile dilution was performed aiming at obtaining turbidity equivalent to the Mac Farland scale tube $\left(10^{8}\right.$ colony forming unit $\left.[\mathrm{CFU}] \cdot \mathrm{mL}^{-1}\right)$. Subsequently, $10^{4} \mathrm{CFU} \cdot \mathrm{mL}^{-1}$ dilution was performed in sterile saline accordingly. After dilutions, $1 \mu \mathrm{L}$ of the solution was transferred to the center of the Petri dish containing MHA medium for E. aerogenes and S. aureus. Then, the control group received no treatment and had 1 drop of bacterial suspension spread with the aid of Drigalsky loop homogeneously across the plaque surface. In the treatment group, $1 \mu \mathrm{L}$ of the bacterial solution was pipetted into the center of the Petri dish and was sparked with HFE (AF Plus ${ }^{\circledR}$, Tone Derm, Caxias do Sul - RS - Brazil). After treatment, 1 drop of bacterial suspension was spread according to procedure performed with the control group. After tests, plates were incubated at $37^{\circ} \mathrm{C}$ for 24 hours and then colonies were counted, and the results were expressed as $\mathrm{CFU} \cdot 1 \mu \mathrm{L}^{-1}$. All groups were tested in triplicate.

\section{Antibacterial activity of HFE}

Standard E. aerogenes and $S$. aureus strains were divided into control and treated groups. In the treated group, HFE was used with the standard electrode containing neon gas to determine the reddish fluorescence. The sparking technique was applied, in which the electrode was positioned about 
$5 \mathrm{~mm}$ away from the plate, causing the formation of sparks with intensities of 6,8 and $10 \mathrm{~mA}$ (regulated in the equipment), which represent voltage of $100 \%$ for $\mathrm{O}_{3}$ formation. Sparking was applied for each intensity for periods of 30,60 , 90,120 and 180 seconds. The same procedure was performed with the control group; however, no sparking was applied.

\section{Statistical analyses}

All values were expressed as mean \pm standard error of the mean. Data were analyzed by repeated measures analysis of variance, followed by Tukey post hoc, and statistical significance was considered when $p<0.05$.

\section{Results}

The bacterial growth of E. aerogenes at 30, 60, 90, 120 and 180 seconds after irradiation with 6,8 or $10 \mathrm{~mA}$ HFE is presented in Figure 1. Compared with the control group, the spark at intensity of $6 \mathrm{~mA}$ had no bactericidal effect; however, a significant bacterial growth reduction occurred at intensity of $8 \mathrm{~mA}$ at 120 and 180 seconds, and at $10 \mathrm{~mA}$, reduction could already be verified at 30 seconds; however, total bacterial growth inhibition only occurred at $10 \mathrm{~mA}$ at 180 seconds.

For $S$. aureus, there was a strong growth inhibition at all intensities used; however, at $6 \mathrm{~mA}$, absence of bacterium growth was observed after 120 and 180 seconds. By increasing the flashing intensity to 8 and $10 \mathrm{~mA}$, it was observed that the bacterium growth was inhibited after only 30 seconds of irradiation, demonstrating that the higher the intensity, the

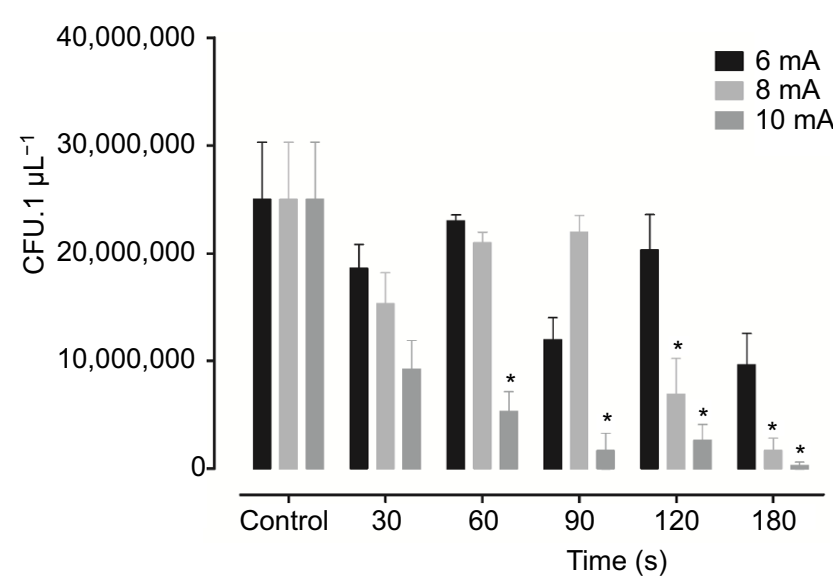

Figure I Antimicrobial effect of the high frequency equipment on the growth of Enterobacter aerogenes standard culture at different times (seconds).

Notes: Results are expressed as mean \pm standard error of the mean. Data were analyzed by one-way analysis of variance, followed by Tukey post hoc. ${ }^{*} p<0.01$, compared with the control group. shorter the time taken for the equipment to induce a bactericidal effect (Figure 2).

\section{Discussion}

Antimicrobial resistance of bacteria, viruses and parasites is a growing public health threat of broad concern to multiple sectors. This increasingly serious problem threatens the achievements of modern medicine and is gradually arousing the interest of governments worldwide. A post-antibiotic era far from being an apocalyptic fantasy, in which minor injuries and common infections could kill, is rather a real possibility in the twenty-first century. Antimicrobial resistance leads to reduced efficacy of therapies, making the treatment of patients difficult, costly, or even impossible, and resulting in prolonged illness and increased mortality. The current absence of new therapeutic agents on the horizon to replace those that have become ineffective adds to the urgency to find new strategies with antimicrobial activity. ${ }^{14}$ These strategies are extremely important for the control of bacterial skin infections, since resistant bacteria also affect skin tissue with varying degrees of severity for patients. ${ }^{9}$ Faced with this necessity, this research presents a promising strategy for the treatment of skin bacterial infections using the HFE.

Enterobacter and Staphylococcus sp. are important human pathogens that are present both in the hospital environment and at home, and responsible for a broad spectrum of infectious diseases of high morbidity and mortality rates. ${ }^{15,16}$ It is of concern that most infections caused by these agents are not sensitive to antibiotic treatment due to

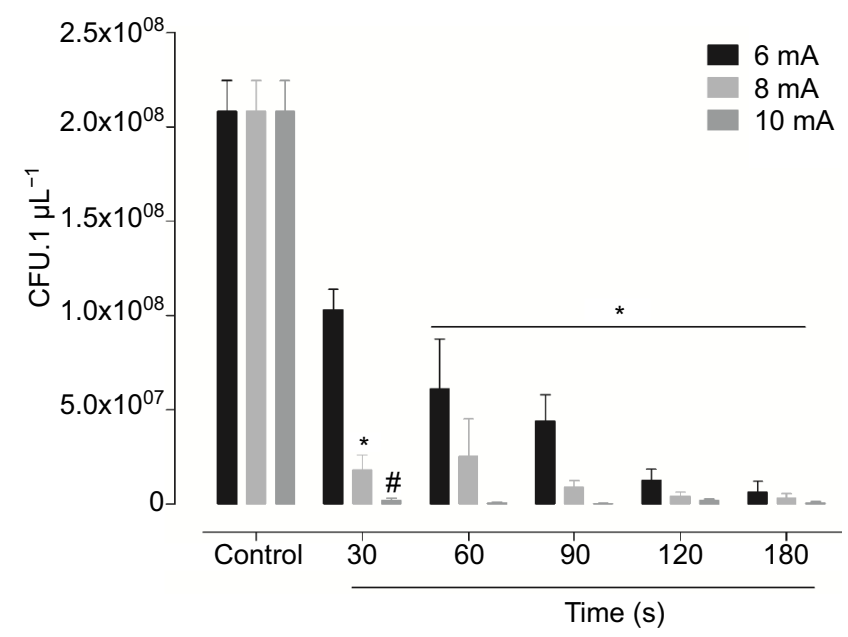

Figure 2 Antimicrobial effect of the high frequency equipment on the growth of Staphylococcus aureus standard culture at different times (seconds).

Notes: Results are expressed as mean \pm standard error of the mean. Data were analyzed by one-way analysis of variance, followed by Tukey post hoc. ${ }^{*} p<0.0$ I, compared with the control group. ${ }^{*} p<0.05$ compared with $6 \mathrm{~mA}$ in 30 seconds. 
the development of bacterial resistance. Our results demonstrate that the use of ozonotherapy through HFE can reduce the growth of E. aerogenes and $S$. aureus cultures in a time and intensity-dependent manner. The same therapy was also effective in patients with pressure ulcers, with improvement in ulcer healing and decrease in the surface area of the lesions. ${ }^{10}$ The anti-inflammatory and bactericidal effects of ozonotherapy were also confirmed on endophthalmitis caused by $S$. epidermidis, with a great reduction of the ocular inflammatory reaction. ${ }^{17}$

HFE acts through an alternating wave that transforms $\mathrm{O}_{2}$ in the air into $\mathrm{O}_{3}$ through sparks. $\mathrm{O}_{3}$ has a cauterizing, healing, thermal, analgesic, anti-inflammatory, fungicidal, bactericidal, bacteriostatic and disinfectant effect. ${ }^{12,18} \mathrm{HFE}$ is commonly used for the treatment of dermatological lesions infected by bacteria and fungi. ${ }^{3}$ In clinical practice, patients better tolerate the application of the intensity of $6 \mathrm{~mA}$. Higher intensities are uncomfortable. However, the results of this research show bacterial growth inhibition with only 30 seconds of irradiation at intensity of 10 $\mathrm{mA}$ of sparking as opposed to 120 seconds of irradiation at intensity of $6 \mathrm{~mA}$ to have the same effect, demonstrating that higher frequency equipment requires less time to provide antimicrobial effect. Thus, it is possible to infer that if low intensity is used, it will be necessary to increase the equipment irradiation time to guarantee bactericidal effect. In addition to the bactericidal, antiseptic, fungicidal and germicidal effects, this therapy modality is low cost, easy to apply, and painless and safe, reducing the costs to the health system and improving the quality of life of the patient. Because of this, and in view of the promising results, HFE can act as an adjuvant to the use of antibiotic therapy in skin infections, if properly used.

\section{Conclusion}

The high frequency apparatus produces bactericidal effect on $S$. aureus and E. aerogenes cultures. However, this effect is observed only at high intensity and prolonged time of application. Further studies should be conducted on this subject, so that this therapy can complement the traditional therapy of skin infections, thus favoring the patient's recovery.

\section{Acknowledgment}

Our immense gratitude to Zipora Morgana Quinteiro dos Santos for the inestimable help with experiments. Universidade Paranaense offered financial support for this research.

\section{Author contributions}

All authors contributed toward data analysis, drafting and revising the paper and agree to be accountable for all aspects of the work.

\section{Disclosure}

The authors report no conflicts of interest in this work.

\section{References}

1. Castro MS, Pilger D, Ferreira MBC, Kopittke L. [Tendências na utilização de antimicrobianos em um hospital universitário, 1990-1996.] Revista Saúde Pública. 2002;36(5):553-558. Portuguese.

2. Silveira GP, Nome F, Gesser JC, et al. [Estratégias utilizadas no combate a resistência bacteriana]. Revista Química Nova. 2006;29(4):844-855. Portuguese.

3. Martins A, Silva JT, Graciola L, et al. [Efeito bactericida do gerador de alta frequência na cultura de Staphylococcus aureus]. Fisioterapia e Pesquisa. 2012;19(2):153-157. Portuguese.

4. Regli AD, Pages JM. Enterobacter aerogenes and Enterobacter cloacae: versatile bacterial pathogens confronting antibiotic treatment. Front Microbiol. 2015;6:392.

5. Tuon FF, Scharf C, Rocha JL, Cieslinsk J, Becker GN, Arend LN. KPC-producing Enterobacter aerogenes infection. Braz J Infect Dis. 2015;19(3):324-327.

6. Almeida MC, Simões MJS, Raddi MSG. [Ocorrência de infecção urinária em pacientes de um hospital universitário]. Revista de Ciências Farmacêuticas Básica e Aplicada. 2007;28(2):215-217. Portuguese.

7. Zavadinack MN, Herreiro F, Bandeira COP, et al. Staphylococcus aureus: incidência e resistência antimicrobiana em abcessos cutâneos de origem comunitária. Acta Scientiarum. 2001;23(3):709-712.

8. Barradas RC. [O desafio das doenças emergentes e a revalorização da epidemiologia descritiva]. Revista Saúde Pública. 1997;31(5):531-537. Portuguese.

9. Sukumaran V. Bacterial skin and soft tissue infections. Aust Prescr. 2016;39(5):159-163.

10. Korelo RIG, Oliveira JJJ, Souza RSA, Hullek RF, Fernandes LC. Gerador de alta frequência como recurso para tratamento de ulceras por pressão: estudo piloto. Fisioter Mov. 2013;26(4):715-724.

11. Sá HP, Nunes HM, Santo LAE, et al. [Estudo comparativo da ação do laser GaAIInP e do gerador de alta frequência no tratamento de feridas cutâneas em ratos: estudo experimental]. ConScientiae Saúde. 2010;9(3):360-366. Latin.

12. Oliveira LMN. [Utilização do ozônio através do aparelho de alta frequência no tratamento da úlcera por pressão]. Revista Brasileira de Ciências da Saúde. 2011;9(30):41-46. Portuguese.

13. CLSI. Performance Standards for Antimicrobial Disk and Dilution Susceptibility Tests for Bacteria Isolated from Animals; Approved Standard Third Edition. CLSI document VET01-A4: 2013.

14. World Health Organization (WHO). Antimicrobial Resistance: Global Report on Surveillance. Geneva: WHO Press; 2014.

15. Gelatti LC, Bonamigo RR, Becker AP, d'Azevedo PA. Staphylococcus aureus resistente a meticilina: disseminação emergente na comunidade. An Bras Dermatol. 2009;84(5):501-506.

16. Koyama N, Inokoshi J, Tomoda H. Anti-infectious agents against MRSA. Molecules. 2013;18(1):204-224.

17. Lake JA, Felberg S, Malavazzi GR, et al. Efeito terapêutico da aplicação intra-ocular de ozônio em modelo experimental de endoftalmite por Staphylococcus epidermidis em coelhos. Arq Bras Oftalmol. 2004;67(4):575-579.

18. Pereira F. Eletroterapia Sem Mistérios. 3rd ed. Rio de Janeiro: Rubio; 2007. 


\section{Publish your work in this journal}

Clinical, Cosmetic and Investigational Dermatology is an international, peer-reviewed, open access, online journal that focuses on the latest clinical and experimental research in all aspects of skin disease and cosmetic interventions. This journal is included on PubMed. The manuscript management system is completely online and includes a very quick and fair peer-review system, which is all easy to use. Visit http://www.dovepress.com/testimonials.php to read real quotes from published authors

Submit your manuscript here: https://www.dovepress.com/clinical-cosmetic-and-investigational-dermatology-journal 